蛋白漏出症を伴った若年性胃腸管ポリポーシスの 1 例

\begin{tabular}{lllllll}
\multicolumn{8}{c}{ 鳥取赤十字病院外科 } \\
山美 柴 田 俊 輔 石 黑 稔 \\
万 木 英 一 西土井 英 昭 村 上
\end{tabular}

患者は48歳，男性。全身倓㤐感，浮腫を主訴に来院し，血液検查で賀血，低蛋白血症 を指摘された．因内視鏡検查で小ポリープが密生して巨大毁㳯を形成している所見を認 め, 組織検查で Hp の感染を伴う若年性ポリポーシスと診断した.自験例は蛋白漏出を伴 う肥厚性胃炎であるメネトリ工病の範潯であると判断し，除菌療法や内科的治療を試み たが、内視鏡所見で進行性の経過をとり，症状の改善がなく胃全摘術を施行した．薬物 治療に抵抗し, 進行性の経過をとる若年性胃ポリポーシスにおいては, 外科的治療も考 慮すべきと考えられた.

索引用語：若年性ポリポーシス,メネトリエ病, Helicobacter pylori

\section{緒 言}

若年性ポリポーシスは大腸に好発する比較的稀な疾 患であるが, 大腸以外の消化管（胃，小腸）に発生す る例が報告され，若年性胃腸管ポリポーシスと㭔ばれ るようになっだ.今回われわれは, 胃に発生した若年 性ポリポーシスが巨大酦毁を形成し, 著明な蛋白漏出 と筫血をきたした症例を経験したので，文献的考察を 加之報告する。

$$
\text { 症例 }
$$

患者：48歳, 男性.

主訴：両下肢，右上肢の浮腫，全身隐意感。

既往歴：平成 8 年腸重積で手術, 同時に胃の粘膜下 腫場を認め, 局所切除を受けた。腫湟の免疫染色では CD34, c-kit, vimentin に陽性で, desmin, $\alpha$-SMA, s-100は陰性であり gastrointestinal stromal tumor と診断された。

家族歴：母が乳癌で手術を受けた。

現病歴: 平成11年 7 月初めより, 全身億急感および 上下肢の浮腫に気づき, 当院内科を受診した，血液検 查で著明な筫血, 低蛋白血症を認め, 精査, 加療目的 で入院となった。

入院時現症：瞼結膜に貣血を認めたが，球結膜には

2003年 8 月 28 日受付 2003 年 12 月 3 日埰用 〈所属施設住所〉

于680-8517 鳥取市尚徳町 117
黄疸は認めず, 口唇, 口腔粘膜に色素沈着を認めなか つた. 胸部理学的所見に異常なく, 腹部は腹壁疫痕へ ルニアを認めた。右上肢，両下肢に浮腫を認めた。

入院時検査所見：白血球增多と著明な小球性貧血を 認めた。生化学検㚗では低蛋白血症を認めたが肝機能, 腎機能等に異常はなかった（表 1 ).

胃内視鏡検查：胃内には粘液が多量に存在し，穹簿 部より胃体下部にかけてポリープが密生して巨大触譬 を形成し，前庭部では小ポリープが散在していた（図 $1 \mathrm{a}, \mathrm{b})$. また, 十二指腸内にも小ポリープの散在を 認めた。

胃 X 線造影検查：多量の粘液のためバリウムの付 着は不良であった。大警を中心に胃管隆部より胃体下 部にかけて巨大雅璧を認めた。

胃生検組織所見：胃体部より strip biopsy を行った 結果，過形成上皮と腺管の搪張所見を認め，間質に強 い炎症細胞浸潤と血管増生がみられた。また, Helicobacter pylori (以下 $H p$ ) 菌も認めた.

治療経過：血液㭘査所見, 胃の画像所見, 組織所見 より若年性ポリポーシスの密生により胃粘膜の肥厚, 分血, 蛋白漏出をきたしたものと判断し保存的治療を 行う方針とした。平成11年 8 月よりオメプラソール20 $\mathrm{mg}$ の投与を行った。しかし内視鏡所見での改善を認 めないため，10月より Hpの除菌療法 (amoxicillin $1,500 \mathrm{mg} /$ day, clarithromycin $400 \mathrm{mg} / \mathrm{day}$, omeprazole 40mg/day）を開始した．大腸内視鏡検査て，横 
表 1 初診時血液検査所見

\begin{tabular}{|crcrcr|}
\hline WBC & $12,700 / \mu \mathrm{l}$ & 血糖値 & $123 \mathrm{mg} / \mathrm{dl}$ & $\mathrm{Na}$ & $140 \mathrm{mEq} / 1$ \\
$\mathrm{RBC}$ & $279 万 / \mu \mathrm{l}$ & T.P & $3.4 \mathrm{~g} / \mathrm{dl}$ & $\mathrm{K}$ & $4.0 \mathrm{mEq} / 1$ \\
$\mathrm{Hb}$ & $4.3 \mathrm{~g} / \mathrm{dl}$ & $\mathrm{GOT}$ & $19 \mathrm{IU} / 1$ & $\mathrm{Cl}$ & $109 \mathrm{mEq} / 1$ \\
$\mathrm{MCV}$ & $56.8 \mathrm{fl}$ & $\mathrm{GPT}$ & $19 \mathrm{IU} / 1$ & $\mathrm{BUN}$ & $17 \mathrm{mg} / \mathrm{dl}$ \\
$\mathrm{Plt}$ & 42.8 万 & LDH & $217 \mathrm{IU} / 1$ & $\mathrm{Crn}$ & $0.7 \mathrm{mg} / \mathrm{dl}$ \\
& & T.B & $0.3 \mathrm{mg} / \mathrm{dl}$ & $\mathrm{CRP}$ & $0 \mathrm{mg} / \mathrm{dl}$ \\
Eosino & $0 \%$ & ALP & $252 \mathrm{IU} / 1$ & フ エリチン & $2 \mathrm{ng} / \mathrm{ml}$ \\
Neutro & $77 \%$ & $\gamma$-GTP & $34 \mathrm{IU} / 1$ & & \\
Lymph & $20 \%$ & Cho-ES & $32 \mathrm{IU} / 1$ & & \\
Mono & $3 \%$ & T-chol & $120 \mathrm{mg} / \mathrm{dl}$ & & \\
\hline
\end{tabular}

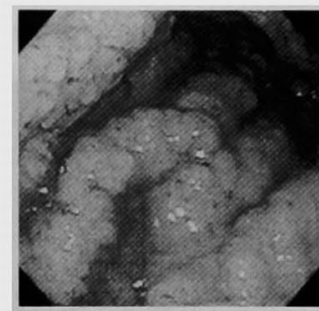

a

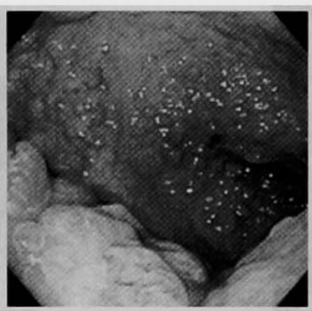

b

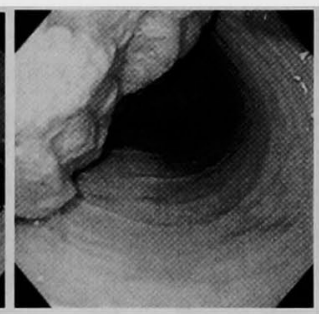

図 1 胃内視鏡所見：a)胃体部は小ポリープが密生し,巨大毁輬を形成している (入院時)。 b ) 前庭部は小ポリープが散在性に存在する (入院時)。 c ) 胃内の ポリープは十二指腸内に脱出している(H13年11月).

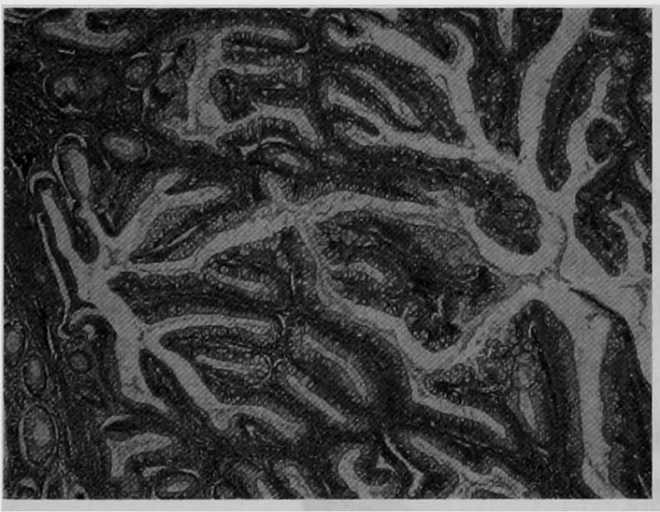

図 2 横行結腸ポリープ組織所見：ポリープの大部分は villous adenomaの組織像であった。

行結腸に $6 \mathrm{~cm}$ 大の山田IV型ポリープを認めたため, 同年11月, 横行結腸ポリープの外科的切除を行った(図 2 ). 平成 12 年 1 月の内視鏡検查では $H p$ の存在は確認 できなかったか，胃内の所見に変化はなく，低蛋白血 症の改善もみられなかった。 以後, 3 力月に 1 度の経 過観察を行い, 前庭部のポリープの数と丈の增加を認 めていた，平成13年11月上旬より突然嘔吐を繰り返す
ようになり，内視鏡検査では食道内に胃内よりポリー プの脱出を認め, 病変は胃全体におよび十二指腸内へ の胃粘膜の脱出所見を認めた (図 $1 \mathrm{c}$ ). 胃X線造影所 見においても胃内のポリープが十二指腸内まで脱出し ている所見を認めた(図 3 )。嘔吐を繰り返し，経口摄 取困難であること， 2 年以上の経過で病変の改善が認 められないことより外科的治療を選択した。

手術および切除標本所見：胃は巨大化しており大䇾 壁の一部が十二指腸内に嵌頓していた，胃全摘術を行 い, Roux-Y 法で再建した。 切除標本では胃穹榢部よ り胃体部までは小ポリープが密在して巨大酦譬を形成 し, 前庭部ではポリープが丈を増して茸状となってい た (図 4 ).

切除標本組織所見：腺窩上皮の過形成からなる粘膜 の肥厚が認められた，腺窩上部は高円柱状で粘液を満 たした細胞からなり, 前庭部では腺管の襄胞状抎張も 認められた。間質は浮腫状となり炎症細胞浸潤と浮腫 を認め若年性ポリポーシスの組織像であった（図５）。

術後経過：経過㟍好で, 術後約 2 年の現在, 総蛋 白は $6.8 \mathrm{~g} / \mathrm{dl}$ となり, 貧血も改善した。 
考察

若年性ポリポーシスは, 1964年 McColl らよよって 初めて提唱され，1970年には Sachatelloら が大腸の みならず胃，小腸にも若年性ポリポーシスが発生する 症例を報告し，若年性胃腸管ポリポーシスと呼ばれる ようになった。胃の若年性ポリポーシスの報告例は少 なく，検索しえた限りでは自験例を含め31例の報告の みであった。

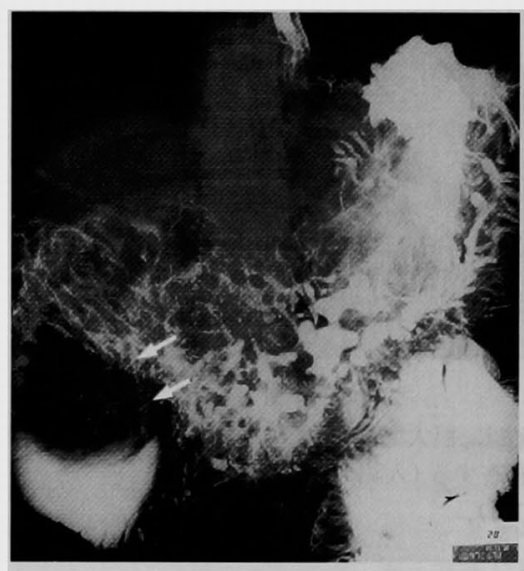

図 3 胃造影所見：胃粘膜へのバリウムの 付着は不良で，胃内より十二指腸内に粘膜 の脱出を認める $(\rightarrow)$.
若年性ポリポーシスの形状に関しては，不整型で大 きさも数 $\mathrm{mm}$ 数 $\mathrm{cm}$ ，数も数個〜無数までさまさま であるが，胃のポリープに関しては胃前庭部が好発部 位といわれている゙!.組織学的には過誤腫であり，異型 を伴わない上皮細胞の增殖を認め，多くの裏胞を形成 し，間質は炎症細胞浸潤，浮腫，うっ血が著明である といわれている゙!.

自験例と同様に胃ポリポーシスを引き起こす疾患と して, 家族性大腸腺腫症の胃底腺ポリポーシス, Peutz-Jeghers 症候群, Cronkhite-Canada 症候群な どが知られている。自験例では家族歴は認めず，胃全

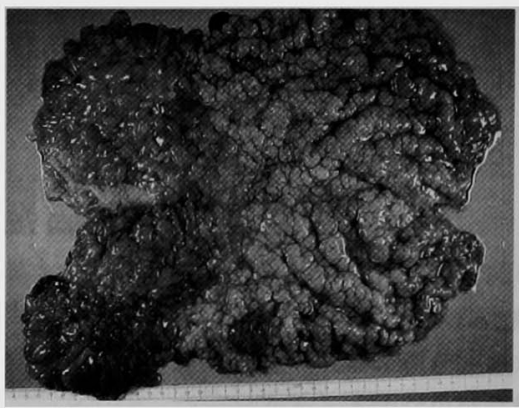

図 4 切除標本写真：穹莑部より体部まで は小ポリープが密生して巨大毁譬状とな り, 前庭部では丈の高いポリープが咠状と なっていた。

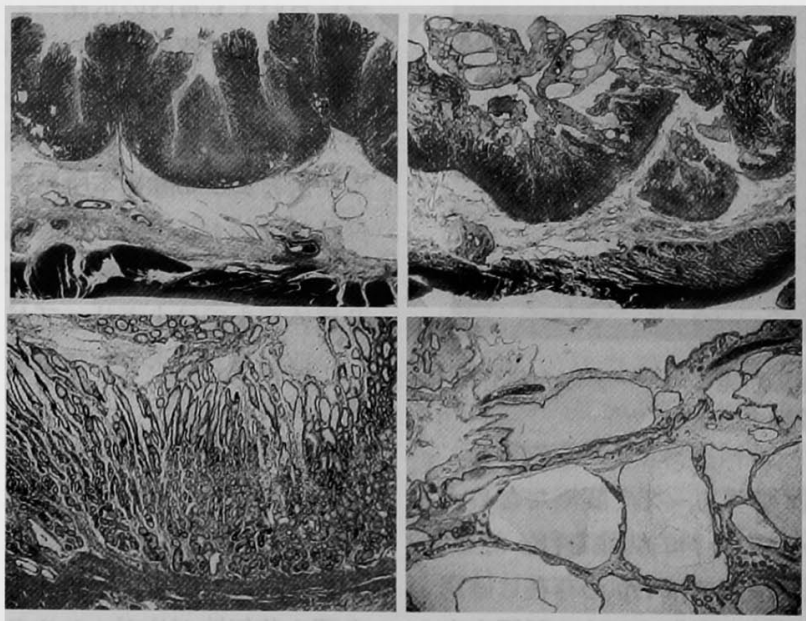

図 5 病理組織所見：a）胃体部ルーぺ像. b) 胃前庭部ルーぺ像. c) 胃体部粘膜像. 腺窝上皮の過形成を認める，d）前庭部粘膜像. 腺管の藻胞状拡張を認める。 
体にポリープの密生が認められており，体部腺領域を 中心に径 $8 \mathrm{~mm}$ 以下の半球状の胃底腺ポリーブが多発 する家族性大腸腺腫症のポリポーシスとは形態的に異 なっていだ). Peutz-Jeghers 症候群も消化管に過誤腫 性のポリポーシスを認める疾患であるが，特徵的な粘 膜筋板の樹枝状增生は自験例では認められず，口唇， 口腔粘膜の色素沈着もないことより籃別は比較的容 易であった．また，自験例で認められた粘膜固有層の 浮腫は粘膜深層部分には認められず，脱毛や爪甲萎縮 などの臨床的特徴がないことが Cronkhite-Canada 症候群との鑑別点であった6).

自験例の胃ポリポーシスは肉眼的には脳回転様の巨

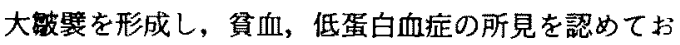
り, 胃の巨大毁䐴を特徵とする肥厚性胃炎であるメネ トリエ病の範䁘に入るものと考えられだ、近年, メネ トリ工病の病因に関しては，Hpの関連性を示唆する 報告がみられるようになり ${ }^{8999}$, 除菌療法で改善した報 告もなされている(0). また H2-ブロッカー ${ }^{11}$ やプロト ンポンプインヒビター121が有効であった報告も散見さ れる. 自験例では胃の生検で Hpが認められたため, $H p$ の関与を疑い除菌療法を行いながら内視鏡での経 過覾察を行ってきた。除菌は成功したもののポリープ は胃前庭部にも密生し，丈を增して十二指腸内に嵌頓 を起こし, 進行性の経過をとった。若年性胃ポリポー シスに関しては，約 8 力の経過で自然消裉した報告 も 1 例認められるが(3), 通常, 内科的治療に上る根治は 不可能といわれ，外科的治療が行われる症例が多いと されている。一方，メネトリ工病で症状の改善した報 告例の多くは，数週から長くても6力月で臨床症状, 画像所見の改善を認めている(4). 自験例のように, $H p$ 陽性の若年性ポリポーシスがメネトリエ病の病態を呈 した場合, Hpの除菌を試みても良いと思われる ${ }^{55}$.し かし，薬物治療に抵抗性で進行性の経過をとる場合に は外科的治療も考慮されるべきである，自験例は，経 過中, 血湤所見の改善を認めず, 内視鏡所見では進行 性の経過をとって招り，早期に手術を行うべきであっ たと反省させられた。また，経過観察を行う場合にお いても，若年性ポリポーシスに胃癌を合併した報告は 高率であるため れる.

\section{結 語}

Hpの感染を伴い, 胃の巨大毁留と蛋白漏出, 責血を 認めた若年性ポリポーシスの1例を経験したので文献 的考察を加え報告した。

\section{文献}

1) Sachatello CR, Pickren JW, Grace JT: Generalized juvenile gastrointestinal polyposis. Gastroenterology $58: 699-708,1970$

2) McColl I, Bussey HJR, Veale AMO, et al: Juvenile polyposis coli. Proc Roy Soc Med 57 : 896-897, 1964

3）平田一郎, 安達岳似, 林勝吉他：大晹㾇と乳癌 を併発した若年性置腸管ポリポーシスの1例。胃 と陽 28:1363-1372, 1993

4）飯田三雄, 小垭陽一郎, 水野 充他：家族性大腸 腺腫症の大晹外腫瘍状病変。胃と腸 $35: 327$ 336, 2000

5）多田正大, 管田信之, 清水誠治：Peutz-Jeghers 症 候群。胃々腸 $35: 342-348,2000$

6) 今村哲理, 栃原正博, 安保智典地: CronkhiteCanada 症候群。胃と腸 35:361-366, 2000

7）多賀須幸男, 土谷春二：胃巨大毁䐴の病態一メ齐 トリ工病の場合. 胃と腸 $15: 531-541,1980$

8) Bayerdorffer E, Ritter MM, Hatz R, et al: Healing of protein losing hypertrophic gastropathy by eradication of Helicobacter pyloriIs Helicobacter pylori a pathogenic factor in Menetrier's disease? Gut 35:701-704, 1994

9) Stolte M, Batz C, Edit S: Giant fold gastritis A special form of Helicobactor pylori associated gastritis. Z Gastroenterol $31: 289-293,1993$

10）八木一芳, 後藤俊夫, 関根厚雄他: Helicobactor pylori 除菌により改善した Menetrier 病のI例. 胃と腸 32：1765-1770，1997

11) 白子順子、武知桂史，腾村直樹他：酸分泌抑制に より低蛋白血症の改善がみられた Menetrier 病 $の 1$ 例. Gastroenterol Endosc 32 : 582-588, 1990

12）奥村嘉章，坂部秀明，宮川明子他：プロトンポン プインヒビターが夻奻したメネトリエ病の1例。 Gastroenterol Endosc $41: 2229-2235,1999$

13）菅智明，赤松泰次，中村 直他：自然消裉した 若年性ポりポーシスの1例. 胃と腸 $36: 1307-$ 1313,2001

14) Kaneko T, Akamatsu T, Gotoh A, et al: Remission of Menetrier's disease after a prolonged period with therapeutic eradication of Helicobactor pylori. Am J Gastroenterol $94: 272$ $-273,1999$

15）平田敬治，杉山朝子，日暮愛一郎地：著明な低蛋 白血症を呈した胃限局性若年性ポリポーシスの1 手術例。胃と腸 $35: 445-450,2000$ 


\title{
A CASE OF GENERALIZED JUVENILE GASTROINTESTINAL POLYPOSIS WITH PROTEIN LOSING GASTROPATHY
}

\author{
Yumi YAMAGUCHI, Shunsuke SHIBATA, Minoru ISHIGURO, \\ Eiichi YURUGI, Hideaki NISHIDOI and Satoshi MURAKAMI \\ Department of Surgery, Tottori Red Cross Hospital
}

\begin{abstract}
A 48-year-old man was seen at the our hospital because of general fatigue and edema. Laboratory studies showed anemia and hypoproteinemia. Endoscopic examination of the stomach revealed numerous small polyps which formed giant folds. Pathological diagnosis was juvenile polyposis with infection with H. Pylori. This case was judged to be one type of protein losing hypertrophic gastropathy, which is so called Menetrier's disease. We tried medication and eradication of $H$. Pylori however, endoscopic findings disclosed progress of the disease and no symptomatic remission was attaind. Total gastrectomy was finally performed. In the case of juvenile gastrointestinal polyposis which progresses or has no response to the medicine, surgical therapy should be considered.
\end{abstract}

